\title{
Torts: The Quest for Appropriate Standards
}

\author{
Harry Kalven, Jr.*
}

Though the quest for appropriate standards centers around constitutional law cases, where judicial latitude is broadest, the problem inheres in all cases whose novelty or whose fortuitous entry into an area of disintegrating precedent affords a comparable latitude. Given the accelerating birthrate of extraordinary novelties, we must achieve some acceleration in the death rate of antiques. $\dagger$

$\mathrm{T}$ HERE IS, I think, a fundamental mystery about evaluation of a judge's performance. Does the judicial function leave enough freedom to the actor so that we can discern distinctive performances? Or is the good judge, by definition, one whose performance is not individualized? I really do not understand what guides judgment in these matters, but my puzzlement does not inhibit my enthusiasm for making judgments about judges. This much at least is clear. We admire judges who can rework and restate old law and we admire judges who can creatively change law just the right amount. In any event, whatever are the criteria, Chief Justice Roger Traynor is an interesting ease in point; indeed he offers an ideal case for exploring the theme of conservatism and creativity in judging.

In his first twenty-five years on the bench, Chief Justice Traynor has written some one-hundred opimions in tort cases. The result is an impressive body of work which not surprisingly has touched virtually all bases. He has given us nothing less than his own personal casebook in torts. ${ }^{1}$

Roger Traynor is a law professor's judge. ${ }^{2}$ His opinions are concise; he raises all the issues; his writing is lucid and to the point. His citations

* A.B. 1935, J.D. 1938, University of Chicago. Professor of Law, University of Chicago.

† Traynor, No Magic Words Could Do It Justice, 49 Carfr. L. Rev. 615, 625 (1961).

1 This is perhaps the place to note that in our personal casebook on torts we use eight of his cases: Gagne v. Bertran, 43 Cal. 2d 481, 275 P.2d 15 (1954); Richards v. Stanley, 43 Cal. 2d 60, 271 P.2d 23 (1954); State Rubbish Collectors Ass'n v. Siliznoff, 38 Cal. 2d 330, 240 P.2d 282 (1952); Satterlee v. Orange Glen School Dist., 29 Cal. 2d 581, 177 P.2d 279 (1947); Escola v. Coca Cola Bottling Co., 24 Cal. 2d 453, 461, 150 P.2d 436, 440 (1944) (concurring opinion); Clinkscales v. Carver, 22 Cal. 2d 72, 136 P.2d 777 (1943); Seeger v. Odell, 18 Cal. 2d 409, 115 P.2d 977 (1941); Imperial Ice Co. v. Rossier, 18 Cal. 2d 33, 112 P.2d 631 (1941). See Gregory \& Katven, Cases and Materiats on Torts 1119, 148, $857,156,647,146,1247$ (1959). And after reading his full torts corpus, it is apparent that we would have been well advised to have used more.

2 See, e.g., Jaffe, Res Ipsa Loquitur Vindicated, 1 Burfato I. Rev. 1, 13 (1951): "We professors prefer Judge Traynor's clear, analytic approach." 
are knowledgeable, economical, and literate-lie has, I think, the best taste in legal citation of any contemporary judge. The style is his own; it is different in torts, for example, from that of Frank, Clark, Hand, Magruder, Holmes, or Cardozo. It is official and impersonal in tone; he is not a plrase-maker, a coiner of epigrams. He is not ironic, as Hand so often is, as lie gives his public reasons. He does not share his difficulties with us, as, he decides cases, however thouglitfully introspective he can be about the judicial process on other occasions. ${ }^{8}$

Since his concurring opinion in Escola $a^{4}$ in 1944 attracted nation-wide attention and since a year or two ago in $Y u b a$ Power ${ }^{5}$ le was able to bring Califorma products liability law into line with that opinion, there is the danger of taking this single daring act of judicial creativity as the full measure of Traynor as a judge. A reading, lowever, of his lifework in torts shows strong strains of conservatism, of non-rebellion against current tort law, and makes the departure in Escola and Yuba Power all the more arresting. Accordingly, we slall begin in the less obvious corner and come to Escola and $Y u b a$ Power by way of conclusion.

\section{I}

His approach is serious and businesslike. $\mathrm{He}$ is not at all selfindulgent. A case in point is Wiseman v. Industrial Accident Commis$\operatorname{sion}^{6}$. where the temptations placed before judicial decorun were considerable. The widow and children of decedent, a commercial traveller who was burned to ideath in a fire in his hotel room in the early morning, seek compensation. The complication is that the decedent was found with:"a woman not his wife,", and there was evidence of drinking. The Commission derned: an award because of the immoral purposes. Justice Traynor reverses. What is of special interest is not the result, whicll miglit today be reached in most jurisdictions, but the sobriety and tact with which lie gets to it.

Whether or not the employee was occupying the room for an immoral and unlawful purpose of his own, he was also occupying it as a necessary incident of his employment which required him to be away from home .... The fact that the employee had a guest in his room while he was off duty in no way detracted from the fact that he was also there on his employer's business, and since the employee's fault

${ }^{8}$ See, e.g., Traynor, Better Days in Court for a New Day's Problems, 17 VAND. $\dot{L}$. REv. 109 (1963).

4 Escola v. Coca Cola Bottling Co., 24 Cal. 2d 453, 461, 150 P.2d 436, 440 (1944) (concurring opinion).

5 Greenman v. Yuba Power Prod., Inc., 59 Cal. 2d 57, 377 P.2d 897, 27 Cal. Rptr. 697 (1962).

B 46 Cal. 2d 570, 297 P.2d 649 (1956). 
is irrelevant if the requirements of the law are met, it is immaterial that the employee's personal purpose in having a guest in his room was immoral and unlawful. ${ }^{7}$

A hallmark of his judging is a patient craftsmanlike working out of things within the frame of reference he has been given by the existing law. One illustration will have to suffice. ${ }^{8}$ In Benton v. Sloss ${ }^{9}$ we see him working with care and elegance on what might be called a routine, if complex, case. Jay, a minor, has attempted to buy a second-hand car from the defendant. His father refuses to sign the contract and tells him to take the car back. Because it is a week-end, Jay is unable to return the car immediately. After a second futile effort to return it, he picks up some friends and goes for a ride in the country. While engaged in racing another car, he crashes due in part to his speed, his inexperience as a driver, and defective brakes. The plaintiffs are the passengers in the Jay car. The defendant car dealer appeals from a judgment against him, and the court in an opinion by Traynor affirms. The trial court had found that Jay was guilty of wilful misconduct in his driving. California has an owner consent statute imposing vicarious liability on owners wliose cars are driven with their implied permission; there is also the customary guest statute exonerating the driver and those responsible for him from liability except for wilful misconduct. Following earlier precedent, Traynor quickly disposes of the owner consent statute as a basis for liability; the statute is limited to vicarious liability for negligence; hence Jay's wilful misconduct falls outside it. The defendant is not liable vicariously, therefore, unless there is an explicit agency relationship, which no one asserts.

The owner consent statute aside, the question then is whether the defendant is liable for his own negligence in selling a defective car. Traynor agrees that "a used car dealer does not insure the safety of a car he sells and is under no duty to disassemble the car to examine its parts."10 Yet he has a duty of reasonable inspection; there is sufficient evidence to support the jury judgment that there was not a proper inspection of the brakes.

The defendant still has three strong points to make: First, given 'Jay's reckless driving, the defect in the brakes was not a cause in fact of the accident; second, there is no proximate cause because defendant

7 Id. at 573, 297 P.2d at 651 .

8 Two other very good examples of this trait are Ash v. Mortensen, 24 Cal. 2d 654, 660, 150 P.2d 876, 879 (1944) (concurring opinion), and Baugh v. Rogers, 24 Cal. 2d 200, 217, 148 P.2d 633, 643 (1944) (dissenting opinion).

938 Cal. 2d 399, 240 P.2d 575 (1952).

$10 \mathrm{Id}$. at $404,240 \mathrm{P} .2 \mathrm{~d}$ at 578. 
is not liable for the intervening reckless driving of Jay; third, he is reheved of liability by the auto guest statute whch limits liability to wilful misconduct. Traynor finds that the defective brakes conjoined with Jay's reckless driving sufficiently to make cause in fact a jury question. He decides further, in full command of modern niceties of proxiinate cause doctrine, that the risk that the brakes would be called upon in an emergency created by the driver's negligence was one of the hazards that defendant could reasonably foresee and was one of the bases for holding him negligent in the first place. Finally, as simply a straight reading of the statutory language, Justice Traynor will not extend the bar of the auto guest statute to the defendant. The defendant is not the driver of the car nor is he "legally responsible for the conduct of such driver." Justice Traynor is not interested in any anomaly that may, as defendant urges, result if only the accidental circumstance that he was not driving his car at the time exposes the defendant to liability. "He would bring himself within the section by construing 'driver' to include 'owner' but the section does not admit of that construction." 11 Any anomaly presumably is in the guest statute itself. The auto guest is not an outcast; he retains, of course, his full remedies against third parties and here the owner of this car is as much a third party as would be the driver of another car.

The result is reached not only lucidly but it is reached tranquilly. There is no talk of the function of owner consent statutes in the quest for solvent defendants ${ }^{12}$ there is no talk of strict liability for used car dealers; there is no philosophical bemusement at how complex the incidence of liability is for an accident of this sort. There is simply a professional utilization of the law already there to reach the desired result.

Another key Traynor trait is the firming up and cleaning up of a sloppy area of law. A fine illustration is furnished by one of his earliest tort opimions, Imperial Ice Company v. Rossier ${ }^{13}$ decided in 1941. Plaintiffs had sued defendants for inducing the breach of a contract not to compete in the sale of ice. The trial court sustained a demurrer on the theory that under California law there was no liability for inducing breach of contract by means that were not "otherwise unlawful." The supreme court reverses. In a concise powerful opinion Justice Traynor structures the law on interference with contract relations. The clarity and precision of formnlation could scarcely be improved upon as he moves from proposition to proposition.

All jurisdictions recognize the tort when the means are independently

11 Ibid.

12 See Gregory \& Kalven, Cases and Materials on Torts 627 (1959); Shulman \& Jasces, Cases and Materials on Torts 654 (1952).

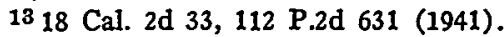


tortious; most jurisdictions also find a tort "for inducing a breach of contract by the use of moral, social or economic pressures, in themselves lawful unless there is sufficient justification for such inducement."14 Justification exists whenever "a person induces a breach of contract to protect an interest that has greater social value than insuring the stability of contract."15 Examples are cited of the interest "in health, safety, and morals," and of the interest of labor in "improving working conditions." But it is clear that it is no justification "simply because [one] is in competition with one of the parties to the contract and seeks to further his own economic advantage."16 Here the values of contract stability outweigh the values of free competition. But absent a contract, competitive freedom is "of sufficient importance to justify one competitor in inducing a third person to forsake another competitor."17 Further, a person is allowed to operate his business by advertising, reducing prices, or other similar means, even though some third parties may be induced thereby to break contracts with competitors in order to deal with him. What is prohibited is the "intentional" injury, brought about "actively and affirmatively."18

There remains then the California precedent in Boyson v. Thorn.19 The case had been read as lolding that there was no tort if the means were otherwise lawful. Traynor carefully re-examines the decision and decides that all the court had meant to say was that there was justification under the circumstances, and not that every time otherwise lawful means are used there is justification. "The statements to the effect that no interference with contractual relations is actionable if the means employed are otherwise lawful were not necessary to the decision and should be disregarded."29 Finally, turning to the pleadings in the case before him, he finds enough allegations of intentional and active inducing of breach to state a cause of action.

Chief Justice Traynor's judicial style is characterized too by his maturity with respect to legal formulas. He is not to be trapped by flatfooted repetition of them. And some of his most helpful opinions show a restating of fornula in terms of purpose so as to save the result. Two fraud cases may be selected for brief illustrations. ${ }^{21}$ In Seeger v. Odell ${ }^{22}$

14 Id. at 35,112 P.2d at 632 .

15 Ibid.

$18 \mathrm{Id}$. at 36,112 P.2d at 633 .

17 Ibid.

18 Id. at 37, 112 P.2d 633.

1098 Cal. 578, 33 Pac. 492 (1893).

29 Imperial Ice Co. v. Rossier, 18 Cal. 2d 33, 38, 112 P.2d 631, 634 (1941).

21 See also his handling of the "exclusive control" requirement of res ipsa loquitur in Rose v. Melody-Lane, 39 Cal. 2d 481, 486, 247 P.2d 335, 338 (1952).

2218 Cal. 2d 409, 115 P.2d 977 (1941). 
he escapes the pitfalls of the maxim that a man must be taken to know the state of his own title; the question is always one of reasonable reliance. At least, under the special facts of that case there can be actionable fraud where the defendant has misrepresented to the plaintiff the state of the plaintiff's title. There is no place in the law of fraud for such a conclusive presumption about what the victim knows, and, to the extent that there is prior authority to the contrary, it is overruled. In Gagne v. Bertran $^{23}$ he handles easily the formula that there can be no recovery for misrepresentations of opinion. In that case the defendant was a test driller and it was precisely his expert opinion that plaintiff was buying and on which he was entitled accordingly to rely.

\section{II}

The examples used thus far have served to mark certain easily identifiable qualities of Traynor as a judge. To catch the full flavor of his judgment, however, requires that we now shift to paired comparisons of certain cases which would roughly appear to involve the same problems or values and watch how carefully and firmly Justice Traynor discriminates between them.

The first comparison is furnished by State Rubbish Collectors $v$. Siliznoff ${ }^{24}$ and Seffert v. Los Angeles Transit Lines. ${ }^{25}$ In a sense both cases involve legal recognition of emotional harm. In Seffert Justice Traynor files a vigorous dissent against affirming an award for 187,000 dollars of which 134,000 dollars was chargeable to pain and suffering. In'Siliznoff he dehiberately extends California law to recognize as a tort the intentional infliction of serious emotional harm without physical harm.

His stance toward emotional harm as a compensable damage is markedly different in the two contexts. In Seffert he first reviews at some length the current criticism of the award for pain and suffering, ${ }^{20}$ finds it especially "anomalous" under contemporary loss shifting theories of tort damages, and concludes that at best it serves "to ease plaintiff's

2343 Cal. 2d 481, 275 P.2d 15 (1954).

2438 Cal. 2d 330, 240 P.2d 282 (1952).

2556 Cal. 2d 498, 509, 364 P.2d 337, 344, 15 Cal. Rptr. 161, 168 (1961) (dissenting opinion).

${ }^{26}$ See, e.g., Jaffe, Damages for Personal Injury: The Impact of Iusurance, $18 \mathrm{LAw}$ \& Contexar. Рrob. 219 (1953); Plant, Damages for Pain and Suffering, 19 OHro ST. L.J. 200 (1958); Morris, Liability for Pain and Suffering, 59 Corom. L. Rev. 476 (1959). But compare Kalven, The Jury, the Law, and the Personal Injury Damage Award, 19 OHo Sx. L.J. 158 (1958); Blum and Kalven, Public Law Perspectives on a Private Law Problem-Auto Compensation Plans, 31 Unrv. CHI. L. Rev. 641, 672-74 (1964). 
discomfort and to pay for attorney fees for which plamtiffs are otherwise not compensated."27 But this is a rule of law too well settled for the court to alter; "any change in this regard must await reexamination by the legislature.". $\mathrm{He}$ then finds that the particular award was excessive when compared to other cases and that the excess was due to the prejudicial argument of counsel in using a variant of the per diem rhetoric on pain and suffering-he had asked for 2,000 dollars per year for the remainder of plaintiff's life.

In Siliznoff the defendant is sued on notes given in purchase of a garbage collection route. Garbage collection appears to be in the hands of a racketeering umion, and defendant claims the notes were secured by duress, and he counterclaims for an assault. He is awarded compensatory and punitive damages and the supreme court affirms. There is evidence that plaintiffs threatened defendant with a physical beating and with cutting his tires and other violence. On appeal the plaintiffs argue the familiar rule that future threats cannot be an assault. Traynor decides to move to a full blown tort for the intentional causing of serious emotional disturbance. He has precedent allowing recovery where the emotional disturbance has resulted in physical harm; the novelty of Siliznoff is that he explicity states a rule that will cover cases in which there is only serious emotional harm. Traynor makes the expansion of liability through a careful use of the Restatement, thus giving it a non innovative look. He capitalizes on a well known change in the Restatement position on emotional harm between 1934 and 1948. ${ }^{29}$ Having made the reform on the authority of the Restatement, Justice Traynor then deals briefly with the policy arguments and makes a neat point about the arbitrariness of requiring physical illness as a mark of authenticity: "The jury is ordinarily in a better position however to determine whether outrageous conduct results in mental distress than whether that distress in turn results in physical injury."30 Apart from his heavy reliance on the Restatement there are two other points of note. First, he does not attempt to restate the traditional law of assault so as to include

27 Seffert v. Los Angeles Transit Lines, 56 Cal. 2d 498, 511, 364 P.2d 337, 345, 15 Cal, Rptr. 161, 169 (1961).

28 Ibid.

29 In 1934 the original RestatemeNT, TorTs \$ 46 provided that the intentional causing of emotional disturbance alone "does not subject the actor to liability." In 1948, § 46 was amended to read: "One wbo, without a privilege to do so, intentionally causes severe emotional distress ...." Id. \& 612 (Supp. 1948). There has been a good deal of law journal commentary on the issue. See, e.g., Gregory \& KaIVEN, Cases and Materials on Torts 848-60 (1959) (c. "Is There a Generic 'New Tort' Emerging?").

30 State Rubbish Collectors Ass'n v. Siliznoff, 38 Cal. 2d 330, 338, 240 P.2d 282, 286 (1952). 
serious future threats. And second, although there was evidence of physical illness in this case, he does not rely on it to establish sufficient physical illness to permit recovery within existing California precedents.

The difference between the situations is clear. Chief Justice Traynor is too sound a judge to have either a monolithic hostility toward or a monohthic enthusiasm for damages for emotional harm. Sucl damages are treacherous to measure, but their function is arguably quite different depending on whether liability is for intentional or negligent conduct. In the one case the indignity is deliberate and the damages are essentially punitive; in the other case the indignity is inadvertent and the problem is one of devising a feasible widespread compensation system. As he says of such damages in Seffert: "They becone increasingly anomalous as emphasis shifts in a mechanized society from ad loc punishment to orderly distribution of losses through insurance and the price of goods or of transportation."31 Further in Siliznoff he is willing without legislation to make a modest change in the law because it is modest and because he can do so as a partner, so to speak, of the Restatement; in Seffert he is not willing to make what would be a major change in the law, but defers to the legislature and rests with correcting the evil in the particular case.

Two libel cases, Werner v. Southern California Newspapers ${ }^{32}$ and McLeod v. Tribune Publishing Company, ${ }^{33}$ provide another useful study of contrasts and highlight Justice Traynor's sense of the judicial role in different contexts. In Werner the issue is the constitutionality of the California retraction statute which limits a plaintiff to special damages in a libel action against radio stations and newspapers unless lie has first requested and has failed to receive a retraction or correction. ${ }^{34}$ In upholding the constitutionality Chief Justice Traynor reviews with sympathy various criticisms of the law of libel. He concludes that the arbitrariness of the distinction between libel and slander, and consequently between the occasions where general damages are or are not permitted, and the dangers of excessive recoveries under general damages where in fact there has been no injury are sufficient considerations to provide a basis for reasonable legislative judgnient restricting the cause of action for hbel. Further, the tendency of the law of hibel to inhibit the free flow of communication is a factor to whicls the legislature nuay properly give weight.

In McLeod, decided some nine years later, the question is one of

31 Seffert v. Los Angeles Transit Lines, 56 Cal. 2d 498, 511, 364 P.2d 337, 345, 15 Cal.

Rptr. 161, 169 (1961) (dissenting opinion).

3235 Cal. 2d 121, 216 P.2d 825 (1950).

3352 Cal. 2d 536, 343 P.2d 36 (1959).

34 See generally Morris, Inadvertent Newspaper Libel and Retraction, 32 ILI. L. REv. 36 (1937). Compare MORRIS, TORTS 297 (1953), criticizing the California statute. 
applying California's "innocent interpretation" rule. Prior cases seem to suggest that if the statement in question were susceptible to an innocent interpretation, the plaintiff was limited to special damages. Justice Traynor thus had at hand a judicially created doctrine which as in Werner tended to limit libel actions, except in rare cases, to special damages. This time, however, he reinterprets the rule so as to restrict it to statements innocent on their face where extrinsic facts are needed to make thein defamatory. ${ }^{35}$ The result is to weaken the libel per se limitation and accordingly to broaden the base of libel actions. Justice Traynor is moved by a construction of the California Code which defines "a libel on its face" and by a distaste for "the hair sphtting analysis of language" that would be invited by the broader rule. "It would be a reproach to the law to hold that a defendant intent on destroying the reputation of a political opponent by falsely labelling hin a Communist or communist sympathizer could achieve his purpose without liability by casting his defamatory language in the form of an insmuation that

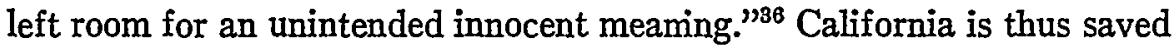
from a resurgence of the idiocies of the doctrine of mitior sensus. ${ }^{37}$ Justice Traynor in this instance then is adamant about liberalizing the law of libel even though it requires that earlier cases inconsistent with the conclusion be "disapproved."

Once again it would be a gross oversimplification of the problem for him to be either all in favor of the law of libel or all against it. To begin with, the device for limiting the action, employed by the legislature in Werner, makes some sense; it substitutes, in effect, retraction for general damages. The device created by the courts in McLeod makes little sense; it invites manipulation of ambiguity by defamers. Perliaps the law of libel should be curtailed, but not all means of doing so are equally attractive. Moreover, the role of the judge is quite different in the two cases; in Werner lie simply must find enough criticism of the law of libel to support legislative reasonableness. In $M c L e o d$ he must translate that criticism into action.

Two routine negligence cases, Neel v. Mannings, Inc..$^{38}$ and Brandenburg v. Pacific Gas \& Electric Co., ${ }^{39}$ offer one more set for comparison. In the first case the plaintiff, a business invitee, injured her head on a projection on the ceiling bordering the stairwell in defendant's restaurant. A judgment notwithstanding the verdict is reversed and a jury verdict for

35 See Gregory \& KaIven, Cases aNd Materiais oN TORTS 974-80 (1959).

36 Burdette v. Rollefson Const. Co., 52 Cal. 2d 536, 551, 343 P.2d 36, 44 (1959).

37 The definitive treatment is Bower, A CODE of tere Law of Actionable Defamation 332-35 (1908).

3819 Cal. 2d 647, 122 P.2d 576 (1942).

3928 Cal. 2d 282, 169 P.2d 909 (1946). 
the plaintiff reinstated with Justice Traynor filing a short pungent dissent. He argues that defendant is not an insurer and that there is no evidence of negligence in the construction or maintenance of the stairway. Moreover, the condition itself gave fair warming. "If the danger is so apparent that the visitor can reasonably be expected to notice it and protect himself, the condition itself constitutes adequate warning and the possessor is under no obhigation to take further action." 40

In Brandenburg the fair warning point is again the issue, and the trial court again grants defendant's motion for judgment notwithstanding the verdict. This time, however, Traynor writes for the unanimous court in reversing. Plaintiff, while standing in a safety zone after getting off a streetcar, is injured by the rcar end of the streetcar as it swings around the curve. Defendants argue that the swing of a streetcar is so well known "to every adult person" that there is no legal duty to warn. Arguably the hazard is as obvious here as it was in Neel. For Traynor, however, the decisive circumstance is that plaintiff was in the safety zone and that defendant knew where he was standing. "The actor's duties vary according to whether he may reasonably expect another to be aware of danger or must know that another's sense of security has been relaxed .... In the present case it should have been apparent to defendants that users of the safety zone would relax their vigilance." The plaintiffs need not think that the overswing would enter the safety zone; therefore this time plaintiffs were entitled to warning and defendant is hable.

\section{III}

These last two cases point to a major characteristic of Roger Traynor's response to the law of torts, namely, an affinity for the niceties of neghigence analysis. In general he gives the impression that he finds the negligence concept intelligible and viable, and he handles it in a series of cases with skill and with a distinctive emphasis. He is clear and rather insistent that to set the standard of care, whether it is done by court or jury, is to inake law, and in his concurring opinion in Toschi v. Christian ${ }^{42}$ he inakes a classic statement of this theory. In Mosley v. Arden Farms $\mathrm{Co}^{43}$ he makes an equally clear statement of the modern theory of proximate cause where again "it should be recoguized that the issue presented is one of law" but where, nevertheless, the jury has a key role.

Since these issues are issues of law, Traynor shows something of

4019 Cal. 2d 647, 658, 122 P.2d 576, 582 (1942).

4128 Cal. 2d 282, 285-86, 167 P.2d 909, 911 (1946).

4224 Cal. 2d 354, 364, 149 P.2d 848, 854 (1944) (separate opinion).

4326 Cal. 2d 213, 157 P.2d 372 (1945). 
Holmes' desire to recapture part of this area for the court. ${ }^{44}$ In Startup v. Pacific Electric $R y$. Co. ${ }^{45}$ where there is a curious echo of Holmes ill-fated opinion in the Goodman ${ }^{48}$ case, the court reverses a directed verdict and would leave to the jury the issue of plaintiff's care in crossing railroad tracks in reliance on wigwag signals. Traynor, concurring, would go farther and hold plaintiff was careful as a matter of law. "A jury is in no better position than this court to answer this question. There is every reason why this issue often raised in practice, should be settled by this court and not left to the oscillating verdicts of juries. The court therefore should determine the standard of reasonable conduct for deciding whether or not the conduct in question was negligent."47

This same emphasis is behind his often expressed view that the violation of criminal statutes should be negligence per se. He first announces his view in opposition to the court in Satterlee v. Orange Glen School District ${ }^{48}$ in 1947 where he provides another splendid statement of theory, this time the theory on which a criminal statute, which by its terms does not cover a civil case, is nevertheless imported into it. $\mathrm{He}$ agrees with Justice Cardozo that if the statute expresses a relevant safety judgment and if the defendant las in fact violated it, there is "no dispensing power" in the jury. By his view it is the judge wlo is exercising his prerogative, under the guidance of the legislative judgment, to rule on negligence as a matter of law. It is really, therefore, just a variant on the issue in the Startup case. Here is a point where I do not happen to agree with the Traynor policy. I would argue that the per se rule tends to produce negligence by trap and thus deprives the neghigence scheme of a needed degree of equity. Nevertheless, there is much to admire in the clarity and sureness with which Justice Traynor states the underlying theory which makes the statute relevant at all.

It falls to Justice Traynor in Clinkscales $v$. Carver ${ }^{49}$ to trace the per se theory througli the perfect test case, a case in which the violation of the legislative standard would technically be no crime. The defendant had gone through a stop sign and collided with plaintiff. It appeared that the ordinance which authorized the placing of stop signs had never become effective criminally because of defects in publication. The defendant, therefore, argued that since there was no effective criminal standard here, the legislative judgment could not be used at all. Traynor

44 Hormes, The Comonon Law 123 (1881).

4529 Cal. 2d 866, 872, 180 P.2d 896, 899 (1947) (concurring opinion).

46 Baltimore \& Ohio R.R. v. Goodman, 275 U.S. 66 (1927); the well-known ill fate is met in Pokora v. Wabash Ry., 292 U.S. 98 (1934).

4729 Cal. 2d 866, 872, 180 P.2d 896, 899 (1947) (concurring opinion).

4829 Cal. 2d 581, 593, 177 P.2d 279, 286 (1947) (concurring opinion).

4922 Cal. 2d 72, 136 P.2d 777 (1957). 
rejects the argument firmly and restates, again with admirable clarity, the basic theory. In the normal case of the criminal statute, the court does not apply the statute but rather adopts its own specific rule of negligence as a matter of law, guided by the fact of legislative judgment. Therefore validity of the criminal statute in a criminal prosecution is irrelevant.

Yet, this enthusiasm for specific standards of care is kept under control. In Knight v. Kaiser ${ }^{50}$ he restates the California law on attractive nuisances bringing it under the jurisdiction of general negligence principles. The Knight case involves injury to a child trespassing on defendant's construction site at which there were large piles of sand and gravel as well as conveyor belts. The ten year old deceased was asphyxiated by the collapse of a sand pile on which he was playing. The majority affirms the sustaining of a demurrer to the wrongful death action on the ground that a common object hike a sand pile is not within the attractive nuisance doctrine, and rehes especially on a firm sequence of California precedents involving bodies of water. Justice Traynor files an effective dissent. $\mathrm{He}$ summarizes ably the anomaly of the "no duty" rules in the area of occupier liability law, and then relying on the Restatement argues that liability, at least to trespassing children, is to be "determined by applying familiar neghigence standards." The matter is, therefore, not one for rigid, specific standards of care, and since there are no sand pile precedents as such, in California, the court is free to apply general negligence principles to the case. When this is done it becomes clear that a large industrial sand pile carries unreasonable risks to young children.

Finally, there is the care with which, statutes apart, he proceeds through the calculus of risk embodied in the neghigence formula. As examples of this care, in addition to those already noted in Neel, Brandenburg, and Knight, we would add only one last pair of illustrations. In Richards $v$. Stanley ${ }^{51}$ he is confronted with judging the conduct of one who left his car unlocked. The car was stolen, and the thief while driving negligently injured the plaintiff. Since the statute involved was explicitly inapplicable to civil suits, the question was one of common law negligence only. In a vigorous opinion Traynor rules this conduct is not negligence. The auto might have been lent to the thief without common law negligence; a fortiori he argues there is no negligence if a thief is enabled to steal it.

A year later in Richardson $v$. Ham ${ }^{52}$ he is confronted with an apparently similar situation and rules the other way. Here leaving the vehicle so that it can be taken by a third party is held to be negligence. The dif- 
ference, of course, is that in Richardson the vehicle in question is not an auto but a bulldozer. Not only was there evidence of strangers tampering with the bulldozer that should have alerted defendants to the dangers of leaving it unattended, but the risks involved are radically different:

The risks arising from internneddling with bulldozers however are entirely different from those arising from the driving of an automobile by a thief. Bulldozers are relatively uncommon and curious children or others attracted by them ordinarily will not know how to operate them. An intermeddler who starts a bulldozer accidentally or otherwise may not be able to stop it and the potentialities of harm from a 26-ton bulldozer in uncontrolled motion are enormous, particularly when it is left on the top of a mesa from which it can escape and injure persons and property below..$^{53}$

\section{IV}

The most interesting tension in the Traynor tort profile is that between his celebrated products liability cases and a series of other cases involving business visitors and the like. The business visitor cases would appear to lay an equal claim to a broad theory of enterprise liability, but Justice Traynor treats them scrupulously within the confines of a neghigence theory.

For example in Loper v. Morrison ${ }^{54}$ there is the familiar question of respondeat superior liability. The employee, who used his own car to collect accounts and solicit new business, deviated from his route somewhat to take a friend home and had the accident in question on the return trip. The majority would leave the scope of authority issue to the jury. Traynor dissents sharply. The question is intrinsically a question of law, and in any event it is clear enough so that it is the court's obligation to decide it; and to decide that there is no recovery because the employee of the defendant business enterprise was on a personal errand. Or in the Neel case, previously discussed, although the defendant is a restaurant and the injured plaintiff is a business visitor, Traynor would again as a matter of law decide against hability. The same result is found in his opinion in Blumberg v. M. E T. Inc. ${ }^{55}$ where plaintiff, a business visitor, falls in the lobby of a downtown hotel belonging to a defendant corporation. The majority would let the issues of negligence and contributory negligence go to the jury. Again, Traynor in sharp dissent would decide both issues adversely to the injured plaintiff as a matter of law. In Laird v. T.W. Mather Inc. ${ }^{58}$ he upsets a verdict in favor of a 79 year old woman who was injured by a fall in the basement of defendants' department store. The case is close on the neghigence issues, and Traynor reverses

53 Id. at 776,285 P.2d at 271.

54 23 Cal. 2d 600, 611, 145 P.2d 1, 6 (1944) (dissenting opinion).

5534 Cal. 2d 226, 230, 209 P.2d 1, 4 (1949) (dissenting opinion).

5651 Cal. 2d 210, 331 P.2d 617 (1958). 
for an error in the instruction on the presumption of due care. Then there is Combs v. Los Angeles Railway Co. ${ }^{57}$ where, again in dissent, Traynor would find contributory negligence per se on the part of the plaintiff who rode on the steps of a street car in violation of a statute. In each of these cases Traynor has as a matter of law ruled against an injured plaintiff suing a business enterprise. To be sure, there are other cases in which he affirms verdicts on belialf of plaintiffs against business enterprises, ${ }^{\text {,8 }}$ but the hability' is always worked out strictly within the confines of conventional negligence limitations.

We come then at last to the products liability cases where Justice Traynor's impact on the law of torts has been most noticed. It is a fair prediction that as the past generation of law students was taught that the most noted chapter of legal history was the growth of law from Winterbottom $v$. Wright ${ }^{59}$ to $M c P$ herson $v$. Buick, ${ }^{80}$ the next generation will learn that that is only half the plot and that the he moves on to - Escola v. Coca Cola Bottling Co. ${ }^{61}$ in 1944 and to Greenman v. Yuba Power Products, Inc. ${ }^{62}$ in 1962.

Escola involved an exploding Coca Cola bottle. The plaintiff, a waitress, was allowed to go to the jury on res ipsa loquitur and recover from the Coca Cola company for negligence. Justice Traynor concurred in the judgment but offered a dramatically different analysis. "Manufacturers' negligence should no longer be singled out as the basis for the plaintiffs right to recover in cases like the present one." ${ }^{\prime 63}$ The new policy considerations are exphicitly outlined::"Even if there is no negligence, however, public policy demands that responsibility be fixed wherever it will inost effectively reduce the hazards to life and health inherent in defective products that reach the market. Those who suffer injury from defective products are unprepared to ineet its consequences. The cost of an injury and the loss of time or health may be an overwhelming misfortune to the person injured and a needless one for the risk of injury can be insured by the manufacturer and distributed among the public as a cost of doing busmess." Moreover, there have been great sociological and technological changes of which the courts must take notice: "As handicrafts have been replaced by mass production with its great markets and transportation facilities, the close relationship between producer and

$5729 \mathrm{Cal} .2 \mathrm{~d} 606,613,177$ P.2d 293, 297 (1947) (dissenting opinion).

58 See, e.g., Burdette-v. Rollefson Const. Co., 52 Cal. 2d 720, 344 P.2d 307 (1959); Raber v. Tumin, 36 Cal. 2d 654, 661, 226 P.2d 574, 578 (1951) (separate opinion); McCordic v. Crawford, 23 Cal. 2d 1, 142 P.2d 7 (1943).

6910 M. \& W. 109, 152 Eng. Rep. 402 (Ex. 1842).

60217 N.Y. 382 , 111 N.E. 1050 (1916).

6124 Cal. 2d 453, 461, 150 P.2d 436, 440 (1944) (concurring opinion).

6259 Cal. 2d 57, 377 P.2d 897, 27 Cal. Rptr. 697 (1962).

6324 Cal. 2d 453, 461, 150 P.2d 436, 440 (1944).

64 Id. at 462,150 P.2d at $440-41$. 
consumer of a product had been altered .... The consumer no longer has means or skill enough to investigate for himself the soundness of a product, even when it is not contained in a sealed package, and his erstwhile vigilance has been lulled by the steady efforts of manufacturers to build up confidence by advertising and marketing devices such as trademarks." $" 5$

Beyond these large scale policy points he is moved by four other considerations: (1) in moving these cases to the jury via res ipsa, "the neghigence rule approaches the rule of strict liability;" (2) where a warranty is available there is already strict hability; (3) it is circuitous to have plaintiff sue the retailer and the retailer sue the manufacturer; (4) in the food cases strict liability has long been recognized. These various lines of argument converge for him on the conclusion that strict liability is required, and he is willing as a judge to make the changes in the law. Finally, as Professor Jaffe noted soine years ago, ${ }^{67}$ Justice Traynor gets no comfort out of the realpolitik of having the change made surreptitiously by a loose use of res ipsa. He is for candor in judicial law making. "If public policy demands that a manufacturer of goods be responsible for their quality regardless of neghigence there is no reason not to fix that responsibility openly."

Justice Traynor returns to the attack in 1949 in Gordon v. Aztec Brewing $\mathrm{Co}^{69}$ This time it is a beer bottle that breaks and again res ipsa loquitur is used to get a jury verdict for the plaintiff. Again Traynor concurs. He argues that on these facts if liability in the case is keyed to negligence there was prejudicial error in the instructions on res ipsa. Accordingly, he would save the result by using the strict liability theory announced in Escola, from which lie quotes biberally. There is increased impatience with an improper use of res ipsa: "If such hability is to be imposed it should be imposed openly and not by spurious application of rules developed to determine the sufficiency of circumstantial evidence in negligence eases." 70

A decade later in Trust v. Arden Farms Co. $^{71}$ it is a milk bottle that breaks. The Court holds there is no liability either on neghigence or warranty with respect either to the dairy or the bottle manufacturer. Traynor concurring as to the bottle manufacturer dissents as to the dairy. Here lie would find sufficient elements of a cause of action for breach

65 Id. at 467,150 P.2d at 443 .

${ }^{68} I d$. at 463,150 P.2d at 441.

o7 Jaffe, Res Ipsa Loquitur Vindicated, 1 Bufraco L. Rev. 1, 13 (1951).

68 Escola v. Coca Cola Bottling Co., 24 Cal. 2d 453, 463, 150 P.2d 436, 441 (1944) (concurring opinion).

6933 Cal. 2d 514, 523, 203 P.2d 522, 528 (1949) (concurring opinion).

$70 \mathrm{Id}$. at $530,203 \mathrm{P} .2 \mathrm{~d}$ at 532 .

7150 Cal. 2d 217, 235, 324 P.2d 583, 594 (1958) (separate opinion). 
of 'warranty. Nevertheless, he returns once again to his Escola theme. Protection of the consumer should not depend "on the intricacies of the law of sales. Liability should not be determined mechanically by fortuitous circumstances."72 Furthermore, in this case the strict liability in food cases offers a compelling analogy. "Whatever the arguments for limiting the manufacturer's strict liability to food stuffs, there is no rational basis for differentiating between food stuffs and their containers."73

In Yuba Power the story reaches its climax-for the moment. ${ }^{74}$ The notable circumstance is that now Justice Traynor has won his fight and writes his strict liability theory in an opmion for a unanimous court. The exact posture of issues in the case is complicated. Plaintiff is injured by a defect in a power tool and sues both the retailer and the manufacturer. There is evidence of neghigence and the jury is instructed on both negligence and warranty theories as the manufacturer's brochure had contained warranties and had been directed at the consumer. The jury brings in a verdict against the manufacturer alone. The main point of the appeal is that plaintiff failed to comply with the provisions of the Sales Act for giving notice in cases of breach of warranty. Hence there could be no recovery on warranty grounds. Since the jury had returned a general verdict, a verdict possibly based on negligence must also be set aside. We have then a case where there is evidence of negligence on the part of the manufacturer and a jury verdict for the consumer but where the overlap with warranty theory endangers the verdict.

In this impasse Traynor comes to the rescue with his strict liability theory. He finds it scarcely necessary to "recanvass the reasons for imposing strict liability on the manufacturers." ${ }^{\prime \prime} \mathrm{We}$ are reminded that "the purpose of such hability is to insure that the costs of injuries resulting from defective products are borne by the manufacturers that put such products on the market rather than by the injured persons who are powerless to protect themselves."76 The more arresting point is the translation into pure tort terms of the kind of warranty talk that has been used to impose strict hability on the manufacturer. In a splendid paragrapl indicative of his characteristic ability to go beyond verbal symbols, he points out that whatever the idiom used, the warranty in these cases has no resemblance to that in sales and that therefore any notice provisions of the Sales Act are irrelevant. That the new liability is imposed by law irrespective of agreement and that the warrantor cannot limit his

72 Id. at 236,324 P.2d at 294-95.

73 Id. at 237, 324 P.2d at 295.

74 Greenman v. Yuba Power Products, Inc., 59 Cal. 2d 57, 63, 377 P.2d 897, 901, 27

Cal. Rptr. 697, 701 (1962).

75 Ibid.

76 Ibid. 
liability "make clear that the liability is not governed by the law of contract but by the law of strict liability in tort. Accordingly, rules defining and governing warranties that were developed to meet the needs of commercial transactions cannot properly be invoked to govern the manufacturers liability to those injured by their defective products unless such rules serve the purposes for which such liability is imposed."77

The performance is impressive. By his steady advocacy, over two decades, of a change Justice Traynor has been able in the end to carry the whole court with him. In so doing he has affected not only the law of California but by prestigeful example, the law of the Umited States. The tension, lowever, between the two lines of liability theory remains arresting. It is easy to ask why the person who falls in a departinent store or who is hit by a street car is any better equipped in general to withstand the loss of accident than the consumer; or again to ask why the business enterprises are any less able to insure and distribute the costs to a wide public, than is the manufacturer. Can the consumer be singled out for special liability protection, or by so doing do we open up the entire tort field to radical revision? Justice Traynor is too candid and too responsible a judge to engage in the strategy of law reform by using the tactic of the foot in the door. Therefore, what commands our attention is why he perceived the two situations as so different. In so doing he has posed for the tort world an issue of interest and importance which is likely to be the topic of excited and exciting controversy for the foreseeable future.

Several lines of distinction suggest themselves. First, he sees the products liability field as set apart by its special history-there is the overlap with warranty, there is the expansive use of res ipsa, there is the circuity of suits against the retailer who then sues the manufacturer, and there is the strong analogy of the food products liability cases. None of these factors are present when, say, a man falls on the stairs in a department store. Second, there is a point about wide loss distribution in this context which he has not yet nuade explicit. The economist would tell us that if we put liability strictly on the manufacturer we are in effect com-

77 There is one later "post-Yuba" Traynor decision that carries farther his obliteration of warranty concepts in his new products liability tort, Vandermark v. Ford Motor Co, 61 A.C. 245, 391, P.2d 168, 37 Cal. Rptr. 896 (1964). Chief Justice Traynor in a case of a defective automobile, highly reminiscent on its facts of $M c$ Pherson, not only repeats his $Y u b a$ rule of strict liability in tort for the manufacturer, but also makes clear that it applies equally to the retailer and that it renders inoperative in tort any disclaimer between retailer and purchaser. As to the retailer's strict liability he observes: "Strict liability on the manufacturer and retailer alike affords maximum protection to the injured plaintiff and works no injustice to the defendants, for they can adjust the costs of such protection between thein in the course of their continuing business relationship." And as to the disclaimer, he notes simply: "Since Maywood Bell is strictly liable in tort, the fact that it restricted its contractual hability to Vandermark is immaterial." 
pelling the consumer through increased prices to buy accident insurance for himself. Perhaps in the great overlap between the consumer public onto whom the cost of protection is to be passed and the consumer who is to be given the protection of strict hability, there is the basis for a distinctive products hability rationale. ${ }^{78}$ Third, and closest to what Chief Justice Traynor himself has told us, there is a difference in the capacity of the injured party to protect himself from larm. What impressed him in $\mathrm{Neel}$ for example was that the defect in the stairway was so obvious that it carried a fair warning. What impresses him in Escola and $Y u b a$ Power is that the consumer can no longer detect defects in the goods he buys. There is the germ of a large idea here. Perhaps negligence is suited only for cases where there is some parity of risk avoiding ability between actor and victim, where, so to speak, risk avoidance is shared between thein. ${ }^{79}$ When, however, the victim can do nothing to protect himself, and this is the Traynor view of the consumer, then strict hability is called for.

One final observation about the tension may be in order. Chief Justice Traynor in his products liability cases may be said to be using the large premises of a public law approach to liability, viewing it is an arrangement for exploiting insurance principles. What makes his performance uniquely interesting is his desire to use the premises as a common law judge, to use them, that is; with the distinctions appropriate to a common law map. It remains to be seen whether this mixture of approaches to liability will prove feasible in the end. ${ }^{80}$

At the outset I said that Roger Traynor was a law professor's judge. This was meant as real and not faint praise. He has respect for his task. He sees law as a body of knowledge, ideally as a structured system of norms rationally ordered. With his every decision he brings the law a little closer to this ideal. In his judging in torts he slows a striking combination of conservatism and creativity. Because of both of these tendencies not only the tort law of California but the tort law of the United States las been all the better for his twenty-five years of service on the bencl..

${ }^{78}$ See Blum \& Kalven, supra note 26 , at $692-703$. But the economist also suggests that it makes less difference than the law has suspected where the loss is left in cases like this.

79 There is a haunting analogy between this division of the accident universe and that suggested by Blackburn, J. in Fletcher v. Rylands, L.R. 1 Exch. 265, 287-7 (1866), where he explained that negligence was the appropriate principle for traffic accidents "upon land or sea" but an inappropriate principle for 'accidents' hetween adjoining landowners. Although he couched the difference in terms of a famous dictum about assumption of risk, he and Chief Justice Traynor may he sharing the same basic perception.

80 Blum \& Kalven, op. cit. supra note 26. 